\title{
Good faith gone bad
}

\author{
Harvey Bialy
}

At a time when literally hundreds of pages of well-intended journalistic comment have been devoted to the benefits the countries of the south will obtain from exploiting their rich genetic "diamond mines" through "mutually equitable agreements" with pharmaceutical and other high-tech biomedical companies in the north, the following would appear a very improbable scenario.

A young researcher in a major institution in a developing country discovers a potentially pharmacologically interesting activity in a native species, and goes on to demonstrate a unique feature that enhances its pharmaceutical potential considerably. $\mathrm{He}$ is invited by a large European drug company to give a seminar at its corporate headquarters in which to discuss these results, and after a certain amount of back-and-forth between the lawyers of his university and those of the company, an agreement is signed in which his institute is to receive between 1 and 3\% of the revenues that might accrue from the development of this new compound.

So far so good. He then provides the mRNA, from which a cDNA library is commercially prepared for the company and from which a clone is isolated, and a patent that contains his name and his institution's is granted, but only after the world's largest drug company, which has previously contacted him secretly and offered a blank check for rights to the mRNA, has contested its validity vigorously though unsuccessfully. Further evidence that the clone is potentially valuable is apparent when the company proceeds to spend in excess of $\$ 25$ million before licensing the product to a pharmaceutical company in Japan. Sounds even better.

Not exactly. Because at this point the by now not-so-young researcher discovers that the European company with which he has in the best, if perhaps not most sophisticated, faith been working has made this deal without seeing the need to inform him, and when confronted contends that it owes his institution nada because the original agreement did not stipulate the licensing to a third party. After long delays, during which threats of lawsuits and public disclosure produce an admission by the company that they do in fact owe something, a figure of $1.6 \%$ of cash payments received to date from the licensee, milestone

Harvey Bialy is a resident scholar at the IBT/UNAM, Cuenervaca, Mexico

(bialy@ibt.unam.mx). payments received in the future, as well as royalties from eventual sales, is offered. Although it has been a long and nasty struggle that has soured him somewhat on the equitability part of the well-worn phrase, and he is now the head of a division at his country's most prestigious biotechnology institute, he is nonetheless relieved, and modestly enough anticipates an influx of cash sufficient to obtain an additional postdoctoral fellow, take on a few more graduate students, and buy some new equipment.

Imagine yourself in this situation and how you would feel when you finally receive an offer from the company in which it claims that three years post-license it has been paid only a total of $\$ 1.5$ million, and thus your university is to receive not quite $\$ 25,000$.

The scenario above is not only far from improbable, it is completely true. The researcher is Alejandro Alagon of the Institute of Biotechnology of the National University of Mexico (IBT/UNAM), the companies involved are Schering AG in Germany, and Teijin in Japan, and the product is a plasminogen activator from the vampire bat.

Begging the question of where the real vampires reside, in 1983 Alagon became interested in the biochemistry underlying the biological phenomenon that when vampire bats from Mexico bite cows or other mammals, the wound, though exceedingly small, bleeds profusely, and that when these same bats bite each other, the wound coagulates almost instantly. He was then engaged in a collaboration with a young German researcher working at a University in Lausanne, Switzerland that also involved hematologically active proteins from exotic species, and Alagon shared this insight as well as some data showing significant clotdissolving abilities of saliva from vampire bats against bovine blood clots. Shortly thereafter, the young German scientist took a position with Schering AG, and took with him knowledge of this potentially novel plasminogen activator.

Their collaboration continued, during which time Alagon discovered that the bat protein had a specificity for fibrin that was many times greater than other commercially produced tissue plasminogen activators (tPAs). This finding, which resulted in the seminar of the scenario above, was particularly pharmaceutically valuable because even the best tPAs do not bind exclusively to fibrin in blood clots, but also activate circulating plasminogen to a small, but nonetheless pharmacologically disturbing degree. Additionally, when the recombinant version of Alagon's
mRNA became available, through the means described above, Schering discovered that only one-third the dose was needed to dissolve human blood clots as that of its most important potential competitor in the billion-dollar clot-dissolving market. Schering pursued the project vigorously for some years, and in October 1997 issued a glowing press release announcing a license agreement for vampire bat plasminogen activator (DSPA) with Teijin of Osaka, Japan that contained the following language: “... the third-generation plasminogen activator has clear advantages over streptokinase/urokinase and tPA ... Schering has compiled a comprehensive preclinical description of the effects of DSPA and demonstrated it in phase I and IIa clinical trials in humans." It even attempted to make public relations hay by including the sentence: "Schering researchers have been able to isolate and characterize the drug substance DSPA in cooperation with colleagues from the University of Mexico," while overlooking the fact that they neither thought to inform their Mexican colleagues of the agreement, nor had any intention of paying them one red cent.

After years of the tortured script sketched earlier, in April of 1999, the director of the IBT wrote to the Schering lawyers acknowledging receipt a few months previously of their admission that UNAM was owed remuneration, and asking for the terms of the Teijin-Schering agreement, which would be held in the strictest confidence. In July, Schering responded that their total payment to date was $\$ 1.5$ million.

Finally, in March of this year, Alagon wrote again to Schering's lawyers asking for some documentation of the claimed $\$ 1.5$ million received from Teijin since 1997 and ended his letter as follows: "We are all very distressed that what should have been a stellar example to the world of the mutual benefits accruing when a major European pharmaceutical company enters into a relationship with a developing country laboratory has deteriorated to this unbecoming display of feet-dragging and tight-fisted behavior on your part. It is still not too late to redeem this unfortunate situation."

Until now, Schering has not seen a need to reply. Its silence, commensurate with its actions, does however speak "whole volumes in folio" to every researcher in the so-called developing countries, and should echo loudly in the chambers of the bureaucrats who endlessly draft their self-serving biodiversity agreements. 